\title{
Keragaan dan Keragaman Genetik Karakter Agronomi Galur Mutan Putatif Gandum Generasi M5
}

\author{
Performance and Genetic Variability of Agronomic Characters \\ of Wheat Putative Mutant Lines on M5 Generation
}

\author{
Eka Bobby Febriantoํ, Yudiwanti Wahyu ${ }^{2 *}$, dan Desta Wirnas ${ }^{2}$ \\ 'Program Studi Pemuliaan dan Bioteknologi Tanaman, Sekolah Pascasarjana, Institut Pertanian Bogor \\ ${ }^{2}$ Departemen Agronomi dan Hortikultura, Fakultas Pertanian, Institut Pertanian Bogor \\ (Bogor Agricultural University), Jl. Meranti, Kampus IPB, Darmaga, Bogor 16680, Indonesia
}

Diterima 17 Maret 2014/Disetujui 10 Juni 2014

\begin{abstract}
The cultivation of wheat in Indonesia especially at medium-low altitude faces problems such as high temperatures whicheffect negativelyon the yield. The aims of this research was to obtain informations on performance, genetic variability and heritability of agronomic characters of wheat putative mutant lines on M5 generation. Genotypes evaluated in the study consisted of 98 putative mutant lines of M5 generation and six varieties as checks, namely Dewata, Selayar, Oasis, Rabe, Kasifbey, and Basribey. The research was conducted at Research Station of IOCRI (Indonesian Ornamental Crops Research Institute), Cipanas. Genotypes were arranged in an augmented, randomized block design. Result of the experiment showed that high heritability estimates were observed for plant height (83.03\%), tiller number (61.75\%), days to flowering (85.41\%), days to maturity (67.45\%), spike length (70.25\%), spikelet number (65.08\%), unfilled grain number $(71.49 \%)$, seed number per spike $(75.16 \%)$, seed weight per spike $(81.69 \%)$, and seed weight per plant $(74.21 \%)$. The estimated genotypic coefficient of variation $(G C V)$ were high for unfilled grain number $(26.35 \%)$ and seed weight per plant $(18.35 \%)$. Based on seed weight per plant, 30 best putative mutant lines were selected.
\end{abstract}

Keywords: Augmented design, heritability, Triticum aestivum

\section{ABSTRAK}

Budidaya gandum di Indonesia, khususnya pada elevasi menengah-rendah menghadapi beberapa kendala, di antaranya suhu lingkungan yang cukup tinggi sehingga berdampak negatif pada daya hasil. Tujuan penelitian ini untuk mendapatkan informasi tentang keragaan, keragaman genetik dan nilai heritabilitas karakter agronomi galur mutan putatif gandum generasi M5. Materi genetik yang digunakan terdiri atas 98 galur mutan putatif gandum generasi M5 dan enam varietas sebagai pembanding, yaitu Dewata, Selayar, Oasis, Rabe, Kasifbey, dan Basribey. Penelitian dilaksanakan di Kebun Percobaan Balai Penelitian Tanaman Hias, Cipanas. Genotipe ditempatkan di lapangan menggunakan rancangan perbesaran (augmented design) dalam kelompok teracak. Hasil penelitian menunjukkan bahwa nilai duga heritabilitas tinggi terdapat pada karakter tinggi tanaman (83.03\%), jumlah anakan (61.75\%), umur berbunga (85.41\%), umur panen (67.45\%), panjang malai (70.25\%), jumlah spikelet (65.08\%), jumlah floret hampa (71.49\%), jumlah biji per malai (75.16\%), bobot biji per malai $(81.69 \%)$ dan bobot biji per tanaman (74.21\%). Nilai duga koefisien keragaman genetik (KKG) tinggi terdapat pada karakter jumlah floret hampa (26.35\%) dan bobot biji per tanaman (18.35\%). Berdasarkan bobot biji per tanaman, diseleksi 30 galur mutan putatif terbaik.

Kata kunci: Augmented design, heritabilitas, $\underline{\text { Triticum aestivum }}$

\section{PENDAHULUAN}

Gandum (Triticum aestivum L.) merupakan tanaman alloheksaploid yang berasal dari daerah subtropis. Menurut Nur (2013) pengembangan gandum di Indonesia selama ini diarahkan pada dataran tinggi dengan ketinggian $>800 \mathrm{~m}$

\footnotetext{
* Penulis untuk korespondensi. e-mail: yudiwanti_wahyu@yahoo. com
}

di atas permukaan laut (dpl) dengan suhu sekitar $22-24{ }^{\circ} \mathrm{C}$. Apabila gandum dibudidayakan di dataran tinggi maka akan bersaing dengan komoditas sayuran dan tanaman hortikultura.

Terbatasnya jumlah varietas gandum yang mampu beradaptasi dengan baik di dataran tinggi Indonesia juga merupakan kendala dalam usaha produksi gandum sehingga upaya untuk menghasilkan varietas gandum masih diperlukan. Sejauh ini, Indonesia telah memiliki tiga 
varietas gandum yang mampu beradaptasi baik di dataran tinggi wilayah tropis yaitu Nias, Dewata dan Selayar serta baru dirilis tiga varietas yaitu Guri-1, Guri-2 dan Ganosha.

Perbaikan sifat agronomi gandum dapat dilakukan dengan berbagai metode pemuliaan tanaman seperti induksi mutasi, persilangan dan rekayasa genetik. Metode mutasi induksi dapat menggunakan mutagen fisika seperti radiasi sinar gamma, fast neutron dan ion beam, atau mutagen kimia antara lain dengan ethyl methane sulfonate (EMS). Penelitian pemuliaan mutasi pada tanaman pertanian umumnya menggunakan iradiasi sinar gamma karena iradiasi sinar gamma memiliki daya tembus yang lebih dalam pada target sel dari material tanaman yang diinduksi (IAEA, 2003). Menurut Syukur et al. (2010), perbaikan karakter melalui program pemuliaan tanaman membutuhkan banyak informasi antara lain tentang keragaman genetik dan heritabilitas.

Nilai duga heritabilitas suatu karakter perlu diketahui untuk menentukan apakah karakter tersebut lebih banyak dipengaruhi oleh faktor genetik atau lingkungan (Yunianti et al., 2010). Nilai heritabilitas yang tinggi berarti faktor keragaman genetik berperan penting dalam penampilan fenotipe pada tanaman (Ishak, 2012). Menurut Sabu et al. (2009) nilai heritabilitas yang tinggi ini memberikan arti bahwa faktor genetik memberikan kontribusi penting dalam proses seleksi berikutnya.

Tujuan penelitian ini adalah untuk mendapatkan informasi tentang keragaan, keragaman genetik dan nilai heritabilitas karakter agronomi galur-galur mutan putatif gandum generasi M5.

\section{BAHAN DAN METODE}

Penelitian dilaksanakan pada bulan April sampai dengan Agustus 2012 di kebun percobaan Balai Penelitian Tanaman Hias, Cipanas dengan ketinggian $>1,000 \mathrm{~m} \mathrm{dpl}$. Materi genetik yang digunakan adalah 98 galur mutan putatif gandum generasi M5 (16 galur M5-Dewata, 9 galur M5-Selayar, 25 galur M5-Oasis, 22 galur M5-Rabe, 21 galur M5-Kasifbey, dan 5 galur M5-Basribey) serta enam varietas pembanding yaitu Dewata, Selayar, Oasis, Rabe, Kasifbey, dan Basribey.

Penelitian disusun menggunakan rancangan perbesaran (augmented design) dalam kelompok teracak dengan genotipe sebagai perlakuan. Genotipe yang digunakan dalam penelitian ini dikelompokkan menjadi dua, yaitu galur mutan putatif generasi M5 dan varietas pembanding, sehingga total terdapat 104 galur. Galur mutan putatif generasi M5 ditanam tanpa ulangan, sedangkan keenam pembanding diulang tiga kali. Areal percobaan dibuat dalam tiga blok dengan ukuran $1.5 \mathrm{~m}$ x $50.4 \mathrm{~m}$ yang masing-masing blok mewakili setiap ulangan dan setiap blok dibagi menjadi plot dengan ukuran $1 \mathrm{~m}$ x $1.5 \mathrm{~m}$. Penanaman dilakukan dengan cara dilarik dan jarak antar larikan sebesar $30 \mathrm{~cm}$, setiap plot terdiri dari tiga larikan. Pemupukan dilakukan dua kali yaitu pemupukan pertama pada umur 10 hari setelah tanam dengan dosis 150 $\mathrm{kg} \mathrm{ha}^{-1}$ Urea, $200 \mathrm{~kg} \mathrm{ha}^{-1}$ SP36 dan $\mathrm{KCl} 100 \mathrm{~kg} \mathrm{ha}^{-1}$ dan pemupukan kedua pada umur 30 hari setelah tanam dengan dosis Urea $150 \mathrm{~kg} \mathrm{ha}^{-1}$.
Pengamatan dilakukan pada lima tanaman contoh dalam setiap plot dengan peubah-peubah sebagai berikut: tinggi tanaman (cm), jumlah anakan, umur berbunga (hari), umur panen (hari), panjang malai (cm), jumlah spikelet per malai, jumlah floret hampa, persentase floret $(\%)$, jumlah biji per malai, bobot biji per malai (g), jumlah biji per tanaman, dan bobot biji per tanaman $(\mathrm{g})$.

Analisis ragam diperoleh dari hasil uji F menggunakan perangkat lunak SAS v9.1. Untuk mengetahui adanya perbedaan nilai tengah antar varietas pembanding dilakukan uji DMRT. Uji t pada karakter agronomi antara galur mutan putatif dengan varietas pembandingnya bertujuan untuk mengetahui secara statistik adanya perbedaan nilai tengah diantara keduanya. Nilai heritabilitas dihitung menggunakan rumus heritabilitas dalam arti luas $\left(\mathrm{h}^{2}{ }_{\mathrm{bs}}\right)$ berdasarkan Sleeper dan Poehlman (2006). Pendugaan heritabilitas diturunkan dari sidik ragam (Tabel 1) dengan menggunakan rumus sebagai berikut:

$$
\sigma_{e}^{2}=K T e / r ; \sigma_{g}^{2}=(K T m-K T e) / r ; \sigma_{p}^{2}=\sigma_{g}^{2}+\sigma_{e}^{2}
$$

$h_{b s}^{2}=\left(\sigma_{g}^{2} / \sigma_{p}^{2}\right) \times 100 \% ; \mathrm{KKG}=\left(\sqrt{\sigma_{g}^{2}} / X\right) \times 100 \%$.

Keterangan:

$h_{b s}^{2}=$ heritabilitas arti luas; $\sigma_{e}^{2}=$ ragam lingkungan;

$\sigma_{p}^{2}=$ ragam fenotipe; $\sigma_{m}^{2}=$ ragam genetik (mutan).

Menurut Zen dan Bahar (1996), nilai heritabilitas diklasifikasikan sebagai berikut: $0<\mathrm{h}^{2} \leq 20 \%$ (rendah); $20 \%$ $<\mathrm{h}^{2}<50 \%$ (sedang); 50\% $\leq \mathrm{h}^{2}<100 \%$ (tinggi). Kriteria koefisien keragaman genetik (KKG) relatif adalah rendah $(0 \%<x<25 \%)$, agak rendah $(25 \%<x<50 \%)$, cukup tinggi $(50 \%<\mathrm{x}<75 \%)$, dan tinggi $(75 \%<\mathrm{x}<100 \%)$ (Moedjiono dan Mejaya, 1994).

\section{HASIL DAN PEMBAHASAN}

Hasil analisis ragam menunjukkan bahwa galur mutan putatif berpengaruh pada keragaan karakter tinggi tanaman, umur berbunga, persentase floret hampa, jumlah biji per malai, bobot biji per malai dan bobot biji per tanaman (Tabel 2). Hal ini mengindikasikan bahwa terdapat keragaman yang tinggi pada galur mutan putatif yang dievaluasi dan berpotensi menghasilkan galur yang terbaik. Cek atau varietas pembanding berpengaruh pada hampir semua keragaan karakter agronomi, kecuali pada karakter jumlah anakan, jumlah biji per malai dan jumlah biji per tanaman. Hal ini membuktikan bahwa terdapat keragaman yang tinggi sehingga menghasilkan perbedaan penampilan karakter dari masing-masing varietas pembanding yang diuji. Mohibullah et al. (2011) melaporkan bahwa pada100 aksesi gandum yang mereka teliti terdapat keragaman pada karakter jumlah spikelet per malai, bobot biji per tanaman dan produksi per hektar. Baloch et al. (2013) dan Kumar et al. (2014) juga melaporkan bahwa terdapat keragaman untuk karakter umur panen, umur berbunga, panjang daun bendera, jumlah anakan, tinggi tanaman, panjang malai, bobot biji per tanaman dan indeks panen.

Uji DMRT memperlihatkan tinggi tanaman varietas Selayar nyata lebih tinggi dibandingkan dengan varietas lainnya (Tabel 3). Umur berbunga varietas Dewata, Kasifbey 
J. Agron. Indonesia 43 (1) : 52 - 58 (2015)

Tabel 1. Sidik ragam rancangan perbesaran (augmented design)

\begin{tabular}{lcccc}
\hline Sumber keragaman & $\mathrm{Db}$ & $\begin{array}{c}\text { Jumlah kuadrat } \\
(\mathrm{JK})\end{array}$ & $\begin{array}{c}\text { Kuadrat tengah } \\
(\mathrm{KT})\end{array}$ & $\begin{array}{c}\text { Harapan kuadrat tengah } \\
(\text { EKT })\end{array}$ \\
\hline Blok & $\mathrm{r}-1$ & $\mathrm{JKb}$ & $\mathrm{KTb}$ & \\
Genotipe & $(\mathrm{m}+\mathrm{c})-1$ & $\mathrm{JKg}$ & $\mathrm{KTg}$ & $\sigma^{2}+\sigma_{g}^{2}$ \\
Mutan putatif $(\mathrm{M})$ & $\mathrm{m}-1$ & $\mathrm{JKm}$ & $\mathrm{KTm}$ & $\sigma^{2}+r \sigma_{c}^{2}$ \\
Cek (C) & $\mathrm{c}-1$ & $\mathrm{JKc}$ & $\mathrm{KTc}$ & $\sigma^{2}$ \\
M vs C & 1 & $\mathrm{JKm} v s \mathrm{c}$ & $\mathrm{KTm} v \mathrm{c}$ & \\
Galat & $(\mathrm{c}-1)(\mathrm{r}-1)$ & $\mathrm{JKe}$ & & \\
Total terkoreksi & $(\mathrm{rc}+\mathrm{m})-1$ & $\mathrm{JKT}$ & & \\
\hline
\end{tabular}

Keterangan: $r$ banyaknya ulangan, m banyaknya galur mutan putatif, c banyaknya varietas, sumber: Sharma (2006), EKT ditetapkan berdasarkan contoh hitungan untuk rancangan yang bersesuaian pada Sharma (2006)

Tabel 2. Pertelaan kuadrat tengah dan uji-F karakter agronomi pada populasi galur mutan putatif generasi M5 dan varietas gandum

\begin{tabular}{|c|c|c|c|c|c|c|}
\hline \multirow[b]{2}{*}{ Karakter } & \multicolumn{3}{|c|}{ Galur mutan putatif } & \multicolumn{3}{|c|}{ Varietas (cek) } \\
\hline & $\begin{array}{l}\text { Kuadrat } \\
\text { tengah }\end{array}$ & $\begin{array}{c}\text { F- } \\
\text { hitung }\end{array}$ & $\operatorname{Pr}>f$ & $\begin{array}{l}\text { Kuadrat } \\
\text { tengah }\end{array}$ & $\begin{array}{c}\text { F- } \\
\text { hitung }\end{array}$ & $\operatorname{Pr}>f$ \\
\hline Jumlah anakan & 4.792 & $1.61 \mathrm{~ns}$ & 0.206 & 4.296 & $1.45 \mathrm{~ns}$ & 0.289 \\
\hline Tinggi tanaman & 177.085 & $4.89 * *$ & 0.005 & 441.442 & $12.20 * *$ & 0.001 \\
\hline Umur berbunga & 9.496 & $5.85 * *$ & 0.002 & 13.822 & $8.52 * *$ & 0.002 \\
\hline Umur panen & 23.049 & $2.07 \mathrm{~ns}$ & 0.102 & 44.433 & $3.99 *$ & 0.030 \\
\hline Panjang malai & 1.102 & $2.36 \mathrm{~ns}$ & 0.068 & 2.250 & $4.82 *$ & 0.017 \\
\hline Jumlah spiklet & 4.109 & $1.86 \mathrm{~ns}$ & 0.140 & 11.309 & $5.13^{*}$ & 0.014 \\
\hline Jumlah floret hampa & 24.070 & $2.51 \mathrm{~ns}$ & 0.056 & 41.135 & $4.29 *$ & 0.024 \\
\hline Persentase floret hampa & 56.810 & $4.10 * *$ & 0.009 & 95.599 & $6.90 * *$ & 0.005 \\
\hline Jumlah biji per malai & 55.530 & $3.03 *$ & 0.029 & 55.748 & $3.04 \mathrm{~ns}$ & 0.064 \\
\hline Bobot biji per malai & 0.100 & $4.46 * *$ & 0.007 & 0.104 & $4.64 *$ & 0.019 \\
\hline Jumlah biji per tanaman & $20,295.125$ & $0.84 \mathrm{~ns}$ & 0.691 & $22,848.682$ & $0.95 \mathrm{~ns}$ & 0.491 \\
\hline Bobot biji per tanaman & 28.980 & $2.88 *$ & 0.035 & 45.597 & $4.53 *$ & 0.020 \\
\hline
\end{tabular}

Keterangan: $* *=$ berpengaruh nyata pada $\alpha=0.01 ; *=$ berpengaruh nyata pada $\alpha=0.05 ; \mathrm{tn}=$ tidak berpengaruh nyata

dan Basribey nyata lebih panjang dibandingkan dengan varietas Selayar dan Rabe. Umur panen varietas Oasis dan Basribey nyata lebih panjang dibandingkan dengan varietas Selayar dan Rabe. Panjang malai varietas Selayar nyata lebih panjang dibandingkan dengan varietas Oasis, Rabe dan Basribey. Jumlah spikelet per malai varietas Dewata dan Kasifbey nyata lebih banyak dibandingkan dengan varietas Selayar dan Rabe. Jumlah floret hampa varietas Dewata dan Kasifbey nyata lebih banyak dibandingkan dengan varietas Rabe dan Basribey. Persentase floret hampa varietas Kasifbey nyata lebih besar dibandingkan dengan varietas lainnya. Bobot biji per malai varietas Dewata dan Oasis nyata lebih besar dibandingkan dengan varietas Selayar, Rabe dan Kasifbey. Bobot biji per tanaman varietas Dewata, Oasis, Kasifbey dan Basribey nyata lebih berat dibandingkan dengan varietas Rabe. Menurut Zecevic et al. (2010) bobot biji per malai merupakan karakter komponen hasil yang sangat penting karena memiliki pengaruh langsung terhadap indeks panen dan hasil. Nur et al. (2012) menambahkan bahwa karakter tinggi tanaman, jumlah anakan produktif, umur panen, panjang malai, jumlah spikelet, luas daun, kerapatan stomata, klorofil a dan ketebalan daun lebih dipengaruhi oleh faktor genetik dibandingkan faktor lingkungan.

Berdasarkan uji t (Tabel 3) galur mutan putatif M5Dewata berbeda nyata lebih kecil dibanding varietas Dewata pada karakter tinggi tanaman, jumlah anakan, umur berbunga, panjang malai, bobot biji per malai, jumlah biji per tanaman dan bobot biji per tanaman, namun berbeda nyata lebih besar pada persentase floret hampa. Galur mutan putatif M5-Selayar berbeda nyata lebih kecil dibanding varietas Selayar pada karakter tinggi tanaman, jumlah anakan dan panjang malai, namun berbeda nyata lebih besar pada karakter umur panen, jumlah spikelet per malai dan persentase floret hampa. Karakter panjang malai dan jumlah spikelet per malai ditentukan oleh pasokan asimilat pada 
Tabel 3. Keragaan karakter agronomi varietas pembanding dan populasi galur mutan putatif M5 gandum

\begin{tabular}{|c|c|c|c|c|c|c|c|c|c|c|c|c|}
\hline Karakter & Dewata & $\begin{array}{c}\text { M5- } \\
\text { Dewata }\end{array}$ & Selayar & $\begin{array}{c}\text { M5- } \\
\text { Selayar }\end{array}$ & Oasis & $\begin{array}{l}\text { M5- } \\
\text { Oasis }\end{array}$ & Rabe & $\begin{array}{l}\text { M5- } \\
\text { Rabe }\end{array}$ & Kasifbey & $\begin{array}{c}\text { M5- } \\
\text { Kasifbey }\end{array}$ & Basribey & $\begin{array}{c}\text { M5- } \\
\text { Basribey }\end{array}$ \\
\hline $\begin{array}{l}\text { Tinggi tanaman } \\
(\mathrm{cm})\end{array}$ & $92.2 b^{1)}$ & $82.8^{* 2)}$ & $105.0 \mathrm{a}$ & $85.2^{*}$ & $74.9 \mathrm{c}$ & $82.6 \mathrm{tn}$ & $81.5 \mathrm{bc}$ & $89.7^{*}$ & $75.7 \mathrm{c}$ & $84.2 \mathrm{tn}$ & $76.1 \mathrm{c}$ & $75.4 \mathrm{tn}$ \\
\hline Jumlah anakan & 11.8 & $9.3^{*}$ & 13.1 & $9.5^{*}$ & 11.4 & $9.9^{*}$ & 9.8 & $9.6 \mathrm{tn}$ & 11.3 & $10.0^{*}$ & 12.8 & $10.3 \mathrm{tn}$ \\
\hline $\begin{array}{l}\text { Umur berbunga } \\
\text { (hari) }\end{array}$ & $61.3 \mathrm{a}$ & $57.1 *$ & $57.7 \mathrm{bc}$ & $58.3 \mathrm{tn}$ & $59.7 \mathrm{ab}$ & $58.1 \mathrm{tn}$ & $55.7 \mathrm{c}$ & $57.8 \mathrm{tn}$ & $60.7 \mathrm{a}$ & $58.2 *$ & $60.3 \mathrm{a}$ & $58.8 \mathrm{tn}$ \\
\hline $\begin{array}{l}\text { Umur panen } \\
\text { (hari) }\end{array}$ & $93.7 \mathrm{abc}$ & $95.8 \mathrm{tn}$ & $89.7 \mathrm{c}$ & $95.8^{*}$ & $98.7 \mathrm{a}$ & $95.9 \mathrm{tn}$ & $90.8 \mathrm{bc}$ & $94.2 *$ & $97.2 \mathrm{ab}$ & $97.7 \mathrm{tn}$ & $98.0 \mathrm{a}$ & $99.4 \mathrm{tn}$ \\
\hline $\begin{array}{l}\text { Panjang malai } \\
(\mathrm{cm})\end{array}$ & $11.3 \mathrm{ab}$ & $10.5^{*}$ & $11.9 \mathrm{a}$ & $10.2 *$ & $10.3 b c$ & 10.5 tn & $9.5 \mathrm{c}$ & $10.3^{*}$ & $11.4 \mathrm{ab}$ & $10.3 \mathrm{tn}$ & $10.5 \mathrm{bc}$ & $10.4 \mathrm{tn}$ \\
\hline $\begin{array}{l}\text { Jumlah spikelet } \\
\text { per malai }\end{array}$ & $22.0 \mathrm{a}$ & $20.7 \mathrm{tn}$ & $18.0 \mathrm{~b}$ & $20.0^{*}$ & $20.8 \mathrm{ab}$ & 20.4 tn & $18.0 \mathrm{~b}$ & $20.5^{*}$ & $22.9 \mathrm{a}$ & $20.9 \mathrm{tn}$ & $20.6 a b$ & $20.1 \mathrm{tn}$ \\
\hline $\begin{array}{l}\text { Jumlah floret } \\
\text { hampa }\end{array}$ & $10.0 \mathrm{a}$ & $10.6 \mathrm{tn}$ & $7.3 \mathrm{ab}$ & $10.3 \mathrm{tn}$ & 7.0ab & $9.2 \mathrm{tn}$ & $4.3 b$ & $12.3^{*}$ & $12.6 \mathrm{a}$ & $11.8 \mathrm{tn}$ & $2.8 \mathrm{~b}$ & $8.4^{*}$ \\
\hline $\begin{array}{l}\text { Persentase floret } \\
\text { hampa }(\%)\end{array}$ & $14.4 \mathrm{~b}$ & $16.7^{*}$ & $13.6 \mathrm{~b}$ & $17.1^{*}$ & $13.4 \mathrm{~b}$ & 14.9 & $13.0 \mathrm{~b}$ & $19.7^{*}$ & $22.9 \mathrm{a}$ & 18.6 & $5.1 \mathrm{c}$ & $13.8^{*}$ \\
\hline $\begin{array}{l}\text { Jumlah biji per } \\
\text { malai }\end{array}$ & 57.2 & $52.7 \mathrm{tn}$ & 52.7 & $51.7 \mathrm{tn}$ & 48.6 & $54.5^{*}$ & 48.1 & $51.0 \mathrm{tn}$ & 48.7 & $52.4 \mathrm{tn}$ & 57.2 & $54.2 \mathrm{tn}$ \\
\hline $\begin{array}{l}\text { Bobot biji per } \\
\text { malai }(\mathrm{g})\end{array}$ & $2.0 \mathrm{a}$ & $1.98^{*}$ & $1.8 \mathrm{~b}$ & $1.8 \mathrm{tn}$ & $2.1 \mathrm{a}$ & $2.0 \mathrm{tn}$ & $1.8 \mathrm{~b}$ & $1.8 \mathrm{tn}$ & $1.8 \mathrm{~b}$ & $1.9 \mathrm{tn}$ & $2.0 \mathrm{ab}$ & $2.2 \mathrm{tn}$ \\
\hline $\begin{array}{l}\text { Jumlah biji per } \\
\text { tanaman }\end{array}$ & 532.6 & $436.6^{*}$ & 515.3 & $446.3 \mathrm{tn}$ & 399.8 & $481.3 \mathrm{tn}$ & 340.6 & $449.0 \mathrm{tn}$ & 420.7 & $467.8 \mathrm{tn}$ & 561.7 & $505.7 \mathrm{tn}$ \\
\hline $\begin{array}{l}\text { Bobot biji per } \\
\text { tanaman }(\mathrm{g})\end{array}$ & $23.6 \mathrm{a}$ & $16.5^{*}$ & $19.0 \mathrm{ab}$ & $16.0 \mathrm{tn}$ & $20.6 \mathrm{a}$ & $17.8 *$ & $13.3 b$ & $15.9 \mathrm{tn}$ & $21.7 \mathrm{a}$ & $16.9 \mathrm{tn}$ & $23.7 \mathrm{a}$ & $20.3 \mathrm{tn}$ \\
\hline
\end{tabular}

Keterangan: ${ }^{1)}$ Angka yang diikuti dengan huruf yang sama pada baris yang sama (antar varietas pembanding: Dewata, Selayar, Oasis, Rabe, Kasifbey, Basribey) untuk tiap karakter menunjukkan tidak berbeda nyata berdasarkan uji jarak berganda Duncan pada $\alpha=0.05{ }^{2)} *=$ berbeda nyata pada taraf $\alpha=0.05 ; \mathrm{tn}=$ tidak berbeda nyata, merupakan hasil uji $\mathrm{t}$ antara populasi galur mutan putatif generasi M5 dengan varietas tetua asalnya (wild type)

fase vegetatif sebagai sumber source untuk membentuk malai pada fase generatif (Nur, 2013). Galur mutan putatif M5-Oasis berbeda nyata lebih kecil dibanding varietas Oasis pada karakter jumlah anakan dan bobot biji per tanaman, namun berbeda nyata lebih besar pada karakter jumlah biji per malai. Galur mutan putatif M5-Rabe berbeda nyata lebih besar dibanding varietas Rabe pada karakter tinggi tanaman, umur panen, panjang malai, jumlah spikelet per malai, jumlah floret hampa dan persentase floret hampa. Galur mutan putatif M5-Kasifbey berbeda nyata lebih kecil dibanding varietas Kasifbey pada karakter jumlah anakan dan umur berbunga. Galur mutan putatif M5-Basribey berbeda nyata lebih besar dibanding varietas Basribey pada karakter jumlah floret hampa dan persentase floret hampa. Menurut Natawijaya (2012) jumlah floret hampa dan persentase floret hampa berdampak langsung terhadap penurunan bobot biji per malai dan bobot biji per tanaman. Karakter ini menggambarkan kemampuan galur dalam menghasilkan polen dan stigma fungsional, kemampuan untuk tetap mempertahankan proses penyerbukan, kemampuan dalam translokasi fotosintat ke malai, dan kemampuan dalam pemenuhan kapasitas sink.

Berdasarkan data pada Tabel 4, masing-masing populasi galur mutan putatif gandum generasi M5 memiliki kisaran nilai yang beragam dan cukup tinggi pada setiap karakter dibanding dengan kisaran nilai varietas. Hal ini menunjukkan bahwa mutasi yang telah dilakukandapat memperbesar keragaman genetik dan keragaan galur-galur mutan putatif yang dihasilkan memiliki dua kemungkinan yaitu lebih baik dari varietas pembanding atau sebaliknya.

Nilai duga heritabilitas karakter yang diamati berkisar 26.23-85.41\% (Tabel 5). Terdapat 10 karakter yang memiliki nilai heritabilitas yang tinggi yaitu karakter tinggi tanaman, jumlah anakan, umur berbunga, umur panen, panjang malai, jumlah spikelet, jumlah biji per malai, bobot biji per malai, bobot biji per tanaman dan jumlah floret hampa. Nilai heritabilitas yang tinggi memberikan informasi bahwa seleksi efektif dilakukan pada karakter tersebut. Beberapa penelitian telah menggunakan komponen nilai heritabilitas sebagai kriteria seleksi pada beberapa komoditi tanaman, antara lain Wirnas et al. (2006) pada kedelai, Sudarmadji et al. (2007) pada wijen, Saleem et al. (2008) pada padi, Martono (2009) pada nilam, Sa'diyah et al. (2009) pada kacang panjang dan Arif et al. (2012) pada cabai.

Hasil penelitian gandum telah dilaporkan oleh beberapa peneliti, antara lain Baloch et al. (2013) menunjukkan nilai heritabilitas tertinggi pada kerakter tinggi tanaman, jumlah anakan, panjang malai, jumlah spikelet per malai, jumlah biji per malai dan bobot biji per tanaman. Laghari et al. (2010) melaporkan heritabilitas tinggi terdapat pada karakter tinggi tanaman, panjang malai, jumlah biji per malai dan bobot biji per malai. Khan dan Naqvi (2011) melaporkan heritabilitas 
Tabel 4. Kisaran nilai tengah karakter agronomi varietas pembanding gandum dan populasi galur mutan putatif M5 gandum

\begin{tabular}{|c|c|c|c|c|c|c|}
\hline Karakter & Dewata & M5-Dewata & Selayar & M5-Selayar & Oasis & M5-Oasis \\
\hline Tinggi tanaman $(\mathrm{cm})$ & $89.3-96.8$ & $54.1-100.8$ & $100.8-108.3$ & $65.9-102.4$ & $62.4-80.9$ & $57.7-106.0$ \\
\hline Jumlah anakan & $10.8-13.5$ & $4.0-12.6$ & $12.5-13.8$ & 4.4-13.2 & $10.8-11.8$ & $3.8-13.4$ \\
\hline Umur berbunga (hari) & $60-62$ & $40-60$ & $57-59$ & $55-62$ & $58-62$ & $52-63$ \\
\hline Umur panen (hari) & $92-95$ & $89-103$ & $85-95$ & $89-102$ & $95-102$ & $89-103$ \\
\hline Panjang malai $(\mathrm{cm})$ & $11.1-11.4$ & $7.1-13.3$ & $11.5-12.3$ & $9.3-11.8$ & $9.2-11.1$ & $8.5-11.8$ \\
\hline Jumlah spikelet per malai & $21.2-22.3$ & $13.2-26.0$ & $17.3-19$ & $17.8-23.0$ & $18.0-22.4$ & $16.0-23.2$ \\
\hline Jumlah floret hampa & $10.5-11.0$ & $3.2-21.2$ & $5.4-9.0$ & $2.2-19.0$ & $3.4-10.3$ & $1.0-23.0$ \\
\hline Persentase floret hampa (\%) & $13.7-15.4$ & $5.3-30.9$ & $11.6-17.1$ & $4.2-31.4$ & $7.1-17.2$ & $1.4-33.5$ \\
\hline Jumlah biji per malai & $50.7-61.5$ & $38.4-66.2$ & $52.3-53.4$ & $39.2-65.6$ & $47.7-49.7$ & $35.0-71.2$ \\
\hline Bobot biji per malai (g) & $2.1-2.3$ & $1.4-2.6$ & $1.8-1.9$ & $1.2-2.3$ & $1.9-2.3$ & $1.4-2.6$ \\
\hline Jumlah biji per tanaman & $496.3-567.3$ & $109.0-656.6$ & $407.8-616.0$ & $124.2-625.0$ & $213.3-505.7$ & $165.2-744.0$ \\
\hline Bobot biji per tanaman (g) & $18.2-27.4$ & $4.0-25.16$ & $18.7-19.3$ & $3.6-23.2$ & $19.1-21.6$ & $6.7-25.1$ \\
\hline Karakter & Rabe & M5-Rabe & Kasifbey & M5-Kasifbey & Basribey & M5-Basribey \\
\hline Tinggi tanaman $(\mathrm{cm})$ & $79.7-83.5$ & $46.4-112.8$ & $66.8-83.3$ & $60.6-114.4$ & $71.0-79.1$ & $67.0-79.7$ \\
\hline Jumlah anakan & $6.3-13.6$ & $3.2-12.6$ & $10.7-12.3$ & $6.6-13.2$ & $12.3-13.3$ & $6.4-13.6$ \\
\hline Umur berbunga (hari) & $53-57$ & $50-62$ & $59-62$ & $52-62$ & $60-61$ & $57-62$ \\
\hline Umur panen (hari) & $89-93$ & $89-102$ & $96-100$ & $89-106$ & $95-102$ & $94-103$ \\
\hline Panjang malai $(\mathrm{cm})$ & $9.2-9.9$ & $6.4-12.6$ & $10.5-13.0$ & $8.5-12.3$ & $10.0-11.2$ & $9.2-11.2$ \\
\hline Jumlah spikelet per malai & $17.3-18.8$ & $13.0-25.6$ & $20.7-25.3$ & $17.8-24.0$ & $20.0-21.0$ & $17.4-21.8$ \\
\hline Jumlah floret hampa & $3.0-5.3$ & $1.8-19.6$ & $6.0-18.3$ & $3.4-18.0$ & $2.2-3.3$ & $3.6-12.6$ \\
\hline Persentase floret hampa (\%) & $12.3-13.5$ & $2.7-28.5$ & $17.6-29.1$ & $6.2-30.8$ & $3.7-6.4$ & $5.6-20.3$ \\
\hline Jumlah biji per malai & $47.3-49.0$ & $35.4-67.6$ & $41.7-58.3$ & $39.0-64.5$ & $56.3-58.7$ & $45.8-68.0$ \\
\hline Bobot biji per malai (g) & $1.7-1.8$ & $1.0-2.2$ & $1.6-2.0$ & $1.1-2.4$ & $1.9-2.1$ & $1.9-2.7$ \\
\hline Jumlah biji per tanaman & $216.7-562.7$ & $70.0-693.4$ & $250.2-681.7$ & $247.0-677.2$ & $536.7-595.0$ & $290.6-827.6$ \\
\hline Bobot biji per tanaman (g) & $9.0-16.9$ & $2.0-22.6$ & $12.9-26.3$ & $6.8-28.9$ & $22.5-24.8$ & $11.7-33.2$ \\
\hline
\end{tabular}

Tabel 5. Nilai duga komponen ragam dan heritabilitas arti luas karakter agronomi galur mutan putatif gandum M5

\begin{tabular}{|c|c|c|c|c|c|c|}
\hline \multirow{2}{*}{ Karakter } & \multirow{2}{*}{$\sigma_{g}^{2}$} & \multirow{2}{*}{$\sigma_{p}^{2}$} & \multicolumn{2}{|c|}{$\mathrm{h}_{\mathrm{bs}}{ }^{2}(\%)$} & \multicolumn{2}{|c|}{ KKG $(\%)$} \\
\hline & & & Nilai & Kriteria & Nilai & Kriteria \\
\hline Tinggi tanaman $(\mathrm{cm})$ & 59.03 & 71.09 & 83.03 & Tinggi & 9.10 & Agak rendah \\
\hline Jumlah anakan & 1.60 & 2.59 & 61.75 & Tinggi & 12.99 & Agak rendah \\
\hline Umur berbunga (hari) & 3.17 & 3.70 & 85.41 & Tinggi & 3.07 & Rendah \\
\hline Umur panen (hari) & 7.68 & 11.39 & 67.45 & Tinggi & 2.89 & Rendah \\
\hline Panjang malai $(\mathrm{cm})$ & 0.37 & 0.52 & 70.25 & Tinggi & 5.84 & Rendah \\
\hline Jumlah spikelet per malai & 1.37 & 2.11 & 65.08 & Tinggi & 5.71 & Rendah \\
\hline Jumlah floret hampa & 8.02 & 11.22 & 71.49 & Tinggi & 26.35 & Tinggi \\
\hline Persentase floret hampa (\%) & 1.64 & 6.26 & 26.23 & Sedang & 7.44 & Agak rendah \\
\hline Jumlah biji per malai & 18.51 & 24.63 & 75.16 & Tinggi & 8.16 & Agak rendah \\
\hline Bobot biji per malai (g) & 0.03 & 0.04 & 81.69 & Tinggi & 9.48 & Agak rendah \\
\hline Jumlah biji per tanaman & $6,765,04$ & $14,794.16$ & 45.73 & Sedang & 17.81 & Cukup tinggi \\
\hline Bobot biji per tanaman (g) & 9.66 & 13.02 & 74.21 & Tinggi & 18.35 & Cukup tinggi \\
\hline
\end{tabular}

Keterangan: $\sigma_{g}^{2}=$ ragam genetik; $\sigma_{p}^{2}=$ ragam fenotipe; $\mathrm{h}_{\mathrm{bs}}{ }^{2}=$ heritabilitas arti luas; $\mathrm{KKG}=$ koefisien keragaman genetik 
tertinggi pada kondisi irigasi kontrol terdapat pada karakter tinggi tanaman, jumlah spikelet, panjang malai dan jumlah biji.

Nilai KKG terendah ditunjukkan oleh karakter umur panen dan nilai KKG tertinggi dihasilkan oleh jumlah floret hampa dan bobot biji per tanaman. Natawijaya (2012), menunjukkan bahwa karakter luas daun bendera, bobot biji per malai dan bobot biji per tanaman memiliki keragaman genetik yang tertinggi sehingga tekanan seleksi dapat dilakukan pada karakter-karakter yang memperlihatkan keragaman genetik yang tinggi, selain itu karakter ini dapat digunakan sebagai karakter seleksi. Nur et al. (2012) juga melaporkan bahwa keragaman genetik yang luas mengindikasikan adanya peluang perbaikan karakter gandum melalui karakter tersebut. Karakter dengan nilai heritabilitas tinggi dan diikuti oleh keragaman genetik luas adalah jumlah anakan produktif, jumlah spikelet dan luas daun.

Nilai KKG absolut $26.35 \%$ ditetapkan sebagai nilai relatif $100 \%$, sehingga diperoleh nilai absolut kriteria tersebut rendah $(0 \% \leq \mathrm{x} \leq 6.60 \%)$, agak rendah $(6.60 \% \leq \mathrm{x}$ $\leq 13.18 \%)$, cukup tinggi $(13.18 \% \leq \mathrm{x} \leq 19.76 \%)$ dan tinggi (19.76\% $\leq \mathrm{x} \leq 26.35 \%$ ). Menurut Bahar dan Zen (1993), karakter yang memiliki nilai heritabilitas tinggi, ragam genetik tinggi, pada umumnya akan memiliki nilai $\mathrm{KKG}$ tinggi untuk masing-masing karakter. KKG digunakan untuk mengukur keragaman genetik suatu sifat tertentu dan untuk membandingkan keragaman genetik berbagai sifat tanaman. Tinggi nilai KKG menunjukkan peluang terhadap usahausaha perbaikan yang efektif melalui seleksi. Berdasarkan pada nilai parameter genetik tersebut dapat dilakukan seleksi terhadap karakter kuantitatif tanpa mengabaikan nilai tengah populasi yang bersangkutan.

Berdasarkan nilai KKG tertinggi maka bobot biji per tanaman dan persentase floret hampa dapat dijadikan sebagai kriteria seleksi. Seleksi galur mutan putatif dilakukan berdasarkan kisaran nilai tengah karakter bobot biji per tanaman (17.11-33.15 g) dan persentase floret hampa (1.38$16.38 \%)$ (Tabel 6).

Tabel 6. Nilai tengah 30 galur mutan putatif M5 gandum terbaik berdasarkan bobot biji per tanaman dan persentase floret hampa

\begin{tabular}{lccccc}
\hline Galur & $\begin{array}{c}\text { Bobot biji } \\
\text { per tanaman }(\mathrm{g})\end{array}$ & $\begin{array}{c}\text { Persentase floret } \\
\text { hampa }(\%)\end{array}$ & Galur & $\begin{array}{c}\text { Bobot biji } \\
\text { per tanaman }(\mathrm{g})\end{array}$ & $\begin{array}{c}\text { Persentase floret } \\
\text { hampa }(\%)\end{array}$ \\
\hline M5-Basribey-4 & 18.25 & 16.00 & M5-Oasis-16 & 17.11 & 13.33 \\
M5-Basribey-5 & 33.15 & 5.55 & M5-Oasis-22 & 20.09 & 10.90 \\
M5-Dewata-1 & 18.56 & 15.71 & M5-Oasis-24 & 24.79 & 7.13 \\
M5-Dewata-12 & 17.17 & 7.59 & M5-Oasis-4 & 17.74 & 13.70 \\
M5-Dewata-15 & 19.97 & 8.30 & M5-Oasis-5 & 21.93 & 10.86 \\
M5-Dewata-16 & 25.16 & 5.33 & M5-Oasis-6 & 25.11 & 1.38 \\
M5-Dewata-7 & 21.33 & 7.96 & M5-Oasis-8 & 23.03 & 15.23 \\
M5-Kasifbey-11 & 20.59 & 14.71 & M5-Oasis-9 & 19.69 & 9.74 \\
M5-Kasifbey-12 & 23.88 & 10.83 & M5-Rabe-18 & 18.44 & 12.30 \\
M5-Kasifbey-14 & 19.85 & 16.38 & M5-Rabe-20 & 22.59 & 2.72 \\
M5-Kasifbey-15 & 28.94 & 6.15 & M5-Rabe-3 & 19.86 & 16.33 \\
M5-Kasifbey-6 & 18.89 & 12.72 & M5-Rabe-4 & 18.69 & 14.29 \\
M5-Oasis-10 & 19.45 & 8.18 & M5-Selayar-1 & 19.52 & 12.17 \\
M5-Oasis-11 & 22.60 & 5.93 & M5-Selayar-2 & 20.77 & 12.97 \\
M5-Oasis-14 & 24.78 & 8.99 & M5-Selayar-3 & 23.20 & 7.64 \\
\hline
\end{tabular}

\section{KESIMPULAN}

Galur mutan putatif gandum mempunyai keragaan yang berbeda dalam hal karakter tinggi tanaman, umur berbunga, persentase floret hampa, jumlah biji per malai, bobot biji per malai dan bobot biji per tanaman. Karakterkarakter pada populasi galur mutan putatif gandum generasi M5 memiliki kisaran yang beragam dan cukup tinggi. Nilai heritabilitas tinggi terdapat pada karakter tinggi tanaman, jumlah anakan, umur berbunga, umur panen, panjang malai, jumlah spikelet, jumlah floret hampa, jumlah biji per malai, bobot biji per malai dan bobot biji per tanaman. Berdasarkan bobot biji per tanaman dan persentase floret hampa diperoleh 30 galur mutan putatif potensial dengan kisaran potensi hasil 17.11-33.15 g per tanaman dan persentase floret hampa $1.38-16.38 \%$.

\section{DAFTAR PUSTAKA}

Arif, A.B., S. Sujiprihati, M. Syukur. 2012. Pendugaan parameter genetik pada beberapa karakter kuantitatif pada persilangan antara cabai besar dengan cabai keriting (Capsicum annuum L.). J. Agron. Indonesia 40:119-124. 
Bahar, H., S. Zen. 1993. Parameter genetik pertumbuhan tanaman, hasil dan komponen hasil jagung. Zuriat 4:4-7.

Baloch, M.J., E. Baloch, W.A. Jatoi, N.F. Vesaar. 2013. Correlations and heritability estimates of yield attributing traits in wheat (Triticum aestivum L.). Pak. J. Agri. Agril. Engg. Vet. Sci. 29:96-105.

[IAEA] International Atomic Energy Agency. 2003. Mutation Breeding News Letter No.46. IAEA, Vienna, Austria.

Ishak. 2012. Sifat agronomi, heritabilitas dan interaksi G X E galur mutan padi gogo (Oryza sativa L.). J. Agron. Indonesia 40:105-111.

Khan, N., F.N. Naqvi. 2011. Heritability of morphological traits in bread wheat advanced lines under irrigated and non-irrigated conditions. Asian J. Agric. Sci. $3: 215-222$

Kumar, N., S. Markar, V. Kumar. 2014. Studi on heritability and genetic advance estimates in timely sown bread wheat (Triticum aestivum L.). Biosci. Discovery 5:64-69.

Laghari, K.A., M.A. Sial, M.A. Arain, A.A. Mirbahar, A.J. Pirzada, M.U. Dahot, S.M. Mangrio. 2010. Heritability studies of yield and yield associated traits in bread wheat. Pak. J. Bot. 42:111-115.

Martono, B. 2009. Keragaman genetik, heritabilitas dan korelasi antar karakter kuantitatif nilam (Pogostemon sp.) hasil fusi protoplas. J. Littri 15:9-15.

Moedjiono, M., J. Mejaya. 1994. Variabilitas genetik beberapa karakter plasma nutfah jagung koleksi Balittas Malang. Zuriat 5:27-32.

Mohibullah, M., M.A. Rabbani, S. Jehan, Zakiullah, A. Amin, Ghazanfarullah. 2011. Genetic variability and correlation analysis of bread wheat (Triticum aestivum L.) accesions. Pak. J. Bot. 43:2717-2720.

Natawijaya, A. 2012. Analisis genetik dan seleksi generasi awal segregan gandum (Triticum aestivum L.) berdaya hasil tinggi. Tesis. Sekolah Pascasarjana. Institut Pertanian Bogor. Bogor.

Nur, A., Trikoesoemaningtyas, N. Khumaida, S. Yahya. 2012. Evaluasi dan keragaman genetik 12 galur gandum introduksi di lingkungan tropika basah. J. Agrivigor 11:230-243
Nur, A. 2013. Adaptasi tanaman gandum (Triticum aestivum L.) toleran suhu tinggi dan peningkatan keragaman genetik melalui induksi mutasi dengan menggunakan iradiasi sinar gamma. Disertasi. Sekolah Pascasarjana. Institut Pertanian Bogor. Bogor.

Sa'diyah, N., T.R. Basoeki, A.E. Putri. 2009. Korelasi, keragaman genetik dan heritabilitas karakter agronomi kacang panjang populasi $\mathrm{F}_{3}$ keturunan persilangan testa hitam x lurik. J. Agrotropika 14:37-41.

Sabu, K.K., M.Z. Abdullah, L.S. Lim, R. Wickneswari. 2009. Analysis of heritability and genetic variability of agronomically important traits in Oryza sativa L. x O. rufipogon Cross. Agron. Res. 7:97-102.

Saleem, M.Y., J.I. Mirza, M.A. Haq. 2008. Heritability, genetic advance, and heterosis in line $\mathrm{x}$ tester crosses of Basmati rice. J. Agric. Res. 46:15-26.

Sharma, J.R. 2006. Statistical and Biometrical Techniques in Plant Breeding. First edition. New Age International. New Delhi. India.

Sleeper, D.A., J.M. Poehlman. 2006. Breeding Field crop $4^{\text {th }}$ ed. Iowa State University Press, Iowa.

Sudarmadji, R. Mardjono, H. Sudarmono. 2007. Variasi genetik, heritabilitas dan korelasi genotipik sifatsifat penting tanaman wijen (Sesamum indicum L.). J. Littri. 13:88-92.

Syukur, M., S. Sujiprihati, A. Siregar. 2010. Pendugaan parameter genetik beberapa karakter agronomi cabai F4 dan evaluasi daya hasilnya menggunakan rancangan perbesaran (Augmented design). J. Agrotropika 15:9-16.

Wirnas, D., I. Widodo, Sobir, Trikoesoemaningtyas, D. Sopandie. 2006. Pemilihan karakter agronomi untuk menyusun indeks seleksi pada 11 populasi kedelai generasi F6. Bul. Agron. 34:19-24.

Yunianti, R., S. Sastrosumarjo, S. Sujiprihati, M. Surahman, S.H. Hidayat. 2010. Kriteria seleksi untuk perakitan varietas cabai tahan Phytophthora capsici Leonian. J. Agron. Indonesia 38:122-129.

Zecevis, V., J. Boskovic, M. Dimitrijevic, S. Petrovic. 2010. Genetic and phenotypic variability of yield components in wheat (Triticum aestivum L.). Bulg. J. Agric. Sci. 16:422-428.

Zen, S., H Bahar. 1996. Penampilan dan pendugaan parameter genetik tanaman jagung. Agric. J. 3:1-9. 